\title{
Immunohistochemical investigation of cells expressing CD21, membrane IgM, CD32 and a follicular dendritic cell marker in the lymphoid tissues of neonatal calves
}

\author{
Kuldeep S. Chattha ${ }^{a}$, Douglas C. Hodgins ${ }^{a, *}$, Josepha DeLay ${ }^{b}$, \\ Nadine Antoine ${ }^{\mathrm{c}}$, Patricia E. Shewen ${ }^{\mathrm{a}}$ \\ a Department of Pathobiology, Ontario Veterinary College, University of Guelph, 50 Stone Road East, Guelph, Ontario, Canada N1G 2W1 \\ b Animal Health Laboratory, University of Guelph, Guelph, Ontario, Canada N1G 2W1 \\ c Department of Morphology and Pathology, Laboratory of Animal Histology, Faculty of Veterinary Medicine, University of Liège, Liège, Belgium
}

\section{A R T I C L E I N F O}

\section{Article history:}

Received 28 January 2010

Received in revised form 12 May 2010

Accepted 14 May 2010

\section{Keywords:}

CD21 (CR2)

CD32 (FcyRIIb)

Membrane IgM (mIgM)

FDCs

Spleen

Retropharyngeal lymph node

Palatine tonsils

Calves

\begin{abstract}
A B S T R A C T
Activation of B lymphocytes in the presence of passive maternal antibodies depends on expression of CD21, membrane IgM and CD32. On colligation with IgM, CD32 inhibits activation whereas CD21 enhances it. Recently, we assessed expression of CD21 and CD32 on $\mathrm{IgM}^{+}$cells from lymphoid tissues of newborn calves by flow cytometry, but this approach does not provide information about spatial distribution within lymphoid compartments. Therefore, histologic sections of lymphoid tissues from newborn and 7-month-old calves were examined using an immunoperoxidase technique. In all calves, CD21 and IgM stained cells were collocated in the cortex and paracortex of the retropharyngeal lymph node, in the marginal zone of the spleen and in lymphoid aggregates of palatine tonsils. Most CD32 ${ }^{+}$cells were in the mantle zone of lymphoid follicles in 7-month-old calves, whereas only weak staining was observed in newborns. A few $\mathrm{CD}_{32}{ }^{+}$cells were also observed in the paracortex at both ages. Absence of $\mathrm{CD} 32^{+}$cells in the center of follicles suggests that $\mathrm{IgM}^{+} \mathrm{CD} 32^{-}$cells observed previously by flow cytometry were from germinal centers. Overall, there were few organized lymphoid aggregates within lymphoid tissues of newborn calves, and follicular dendritic cells were virtually undetectable. Their absence may be an important limitation for neonatal immunization.
\end{abstract}

(C) 2010 Elsevier B.V. All rights reserved.

\section{Introduction}

Neonates have reduced antibody responses following vaccination. This has been attributed to functional limitations of the neonatal immune system and to the suppressive effects of passive maternal antibodies (Marshall-Clarke et al., 2000; Siegrist, 2001; Firth et al., 2005; Chase et al., 2008). The number of B lymphocytes and their optimal activity is important for generation of anti-

\footnotetext{
* Corresponding author. Tel.: +1 519824 4120x54758; fax: +1 5198245930 .

E-mail address: dhodgins@uoguelph.ca (D.C. Hodgins).
}

body responses and for protection against various bacterial and viral infections. The number of naïve $\operatorname{IgM}^{+} \mathrm{B}$ lymphocytes, as determined by flow cytometry, is low in lymphoid tissues and blood of newborn calves and this may limit the neonate's antibody responses (Chattha et al., 2010a,b). As well, expression of various co-stimulatory molecules such as CD80, CD86 and CD21 (complement receptor 2) has been shown to be lower on neonatal human and mouse B lymphocytes (Kaur et al., 2007; Muthukkumar et al., 2000; Rijkers et al., 1998).

In calves, CD21 is constitutively expressed by $\operatorname{IgM}^{+} \mathrm{B}$ cells (Chattha et al., 2009, 2010a). B cell responses are enhanced when CD21 is colligated with the B cell antigen receptor, membrane IgM (mIgM), by complement C3d 
bound to antigen (Dempsey et al., 1996; Lyubchenko et al., 2005). However, various soluble complement components including C3 (which on breakdown forms C3d), are low in neonates (reviewed by Firth et al., 2005).

CD32 (FcyRII) is an IgG Fc binding receptor expressed by $\mathrm{B}$ cells, neutrophils and monocytes, that binds IgG within immune complexes (Nimmerjahn and Ravetch, 2008). The $b$ isoform (Fc $\gamma R$ IIb) of CD32 expressed by B cells has an immunoreceptor tyrosine-based inhibitory motif (ITIM) in the cytoplasmic tail. Colligation of mIgM and CD32 by antigen-antibody complexes suppresses antibody responses by increasing the threshold for activation of antigen-specific B cells (Amigorena et al., 1992; Van den Herik-Oudijk et al., 1994; Gergely and Sarmay, 1996). In neonates with passive maternal IgG antibodies, there is potential for colligation of mIgM with both CD21 and CD32 on B cells by complement bound antigen-antibody complexes. Thus, the relative proportion of $\mathrm{C} 3 \mathrm{~d}$ and $\operatorname{IgG}$ in complexes may control B cell activation or inhibition by regulating the threshold of activation. We have shown that the majority of $\operatorname{IgM}^{+} \mathrm{B}$ lymphocytes in the blood of calves express both CD21 and CD32 (Chattha et al., 2010a). In the spleen and lymph nodes of newborn and 7-week-old calves almost all $\operatorname{IgM}^{+}$B cells express CD21, whereas only $75 \%$ to $83 \%$ of $\operatorname{IgM}^{+}$B cells express CD32, suggesting a possible bias toward activation (Chattha et al., $2010 \mathrm{~b}$ ). However, receptor expression was investigated by flow cytometry, which does not provide information about the location of receptor-expressing cells in the lymphoid tissues. The location of CD21, IgM and CD32 expressing cells can have important implications for immune responsiveness. Therefore, we compared the distribution of cells expressing these receptors in the lymphoid tissues of newborn and 7-month-old calves (as representative of adults) by immunohistochemistry.

Follicular dendritic cells (FDCs) also play an important role in antigen presentation for induction of antibody responses. Complement and Fc receptors, including CD32, on FDCs trap the antigen in its complexed form (antigen-antibody or antigen-complement or antigen-antibody-complement). FDCs display antigen, help in affinity maturation and selection of activated B lymphocytes, and contribute towards formation of germinal centers (GCs), and generation of memory and plasma cells (Tew et al., 2001). The low number of mature FDCs in the lymphoid tissues of neonatal mice correlates with low serum IgG, the small number of antibody secreting cells and low number of GCs in lymphoid tissues (Pihlgren et al., 2003). Limitations of B cells and various accessory cells including FDCs in neonates may partly be responsible for observed poor antibody responses (Marshall-Clarke et al., 2000; Siegrist and Aspinall, 2009). Recently, a new monoclonal antibody FDC-B1 was produced, which is specific for a $28-\mathrm{kDa}$ (as measured by western blotting) surface antigen (postulated to be a glycoprotein) of bovine FDCs, (Melot et al., 2004). It was used in this study to analyse the FDC network in neonatal calves since the number of FDCs in lymphoid tissues could be an important limiting factor for induction of antibody responses.

\section{Materials and methods}

All experimental procedures were approved by the University of Guelph Animal Care Committee and were conducted according to the guidelines of the Canadian Council for Animal Care.

\subsection{Lymphoid tissue samples}

Spleen, retropharyngeal lymph node (RPLN) and palatine tonsils were collected at necropsy from 4 clinically healthy Holstein bull calves. The two newborn calves ( 2 and 5 days of age) were born at the Elora Dairy Research Station, whereas the two 7-month-old calves were born off site but were raised at the Ponsonby Research Station; these two research facilities are operated coordinately by the University of Guelph. Calves received at least four litres of colostrum within $16 \mathrm{~h}$ of birth. Calves were humanely euthanized by intravenous injection of Euthansol (Intervet/Schering-Plough Animal Health, Kirkland, Quebec). $5 \mathrm{~mm} \times 5 \mathrm{~mm} \times 5 \mathrm{~mm}$ sections of tissue were harvested and embedded in OCT compound (TissueTek, Sakura Finetek, Torrance, CA), then snap frozen by dipping in liquid nitrogen for 15-20 s. Frozen tissue samples were kept at $-80^{\circ} \mathrm{C}$ until processed.

\subsection{Immunohistochemistry staining}

$5 \mu \mathrm{m}$ thick serial sections of lymphoid tissues were cut using a cryostat (Leica CM3050 S) and mounted on charged glass slides (Fisher Scientific, Pittsburgh, PA). Cryostat sections were fixed in pre-cooled acetone $\left(-20^{\circ} \mathrm{C}\right)$ for $10 \mathrm{~min}$ at $4{ }^{\circ} \mathrm{C}$, then air-dried at room temperature (RT). Slide-mounted tissue sections were rehydrated in phosphate buffered saline $(\mathrm{pH}=7.4)$ and pre-treated with $0.03 \%$ hydrogen peroxide (Sigma-Aldrich) for $10 \mathrm{~min}$ to block endogenous tissue peroxidases. Slides were washed twice with PBS for $5 \mathrm{~min}$, then blocked with serumfree protein blocking solution (Dako, Carpinteria, CA) for 15-20 min at RT. Sequential tissue sections were stained

Table 1

Monoclonal antibodies (mAb) used in immunohistochemistry.

\begin{tabular}{|c|c|c|c|c|}
\hline Clone & Isotype & Specificity & Working dilution & Source \\
\hline CCG36 (mouse) & $\operatorname{IgG1}$ & Bovine CD32 & $1: 8000$ & $\begin{array}{l}\text { BBSRC/SEERAD Immunological } \\
\text { Toolbox (grant numbers } \\
\text { BBS/B/00255, MRI/094/04) }\end{array}$ \\
\hline CC21 (mouse) & $\operatorname{IgG1}$ & Bovine CD21 & $1: 2000$ & AbD Serotec, Oxford, UK \\
\hline BM-23 (mouse) & $\operatorname{IgG} 1$ & Bovine IgM & $1: 2000$ & Sigma, St. Louis, MO, USA \\
\hline FDC-B1 (mouse) & IgM & $\begin{array}{l}28 \mathrm{kDa} \text { surface antigen on } \\
\text { bovine FDCs }\end{array}$ & $1: 2$ & $\begin{array}{l}\text { Pr E. Heinen, Université de } \\
\text { Liège, Belgium }\end{array}$ \\
\hline
\end{tabular}


(A)

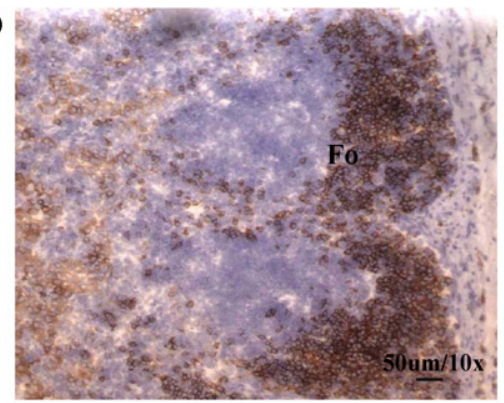

(B)

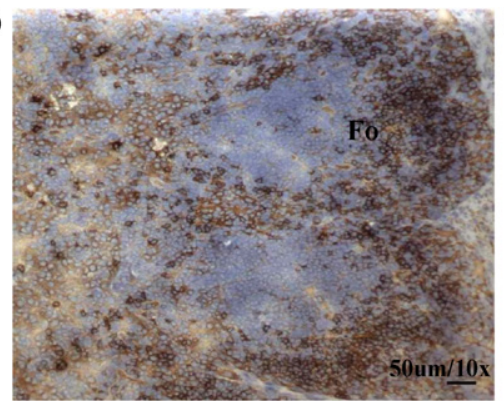

(C)

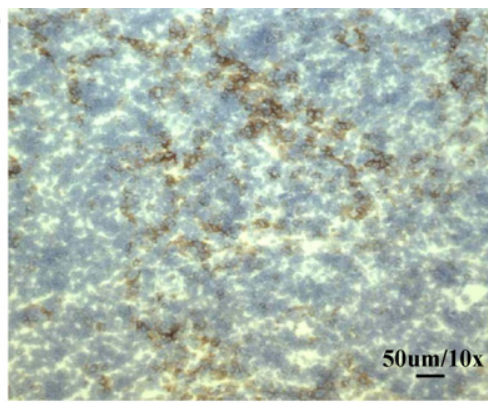

(D)

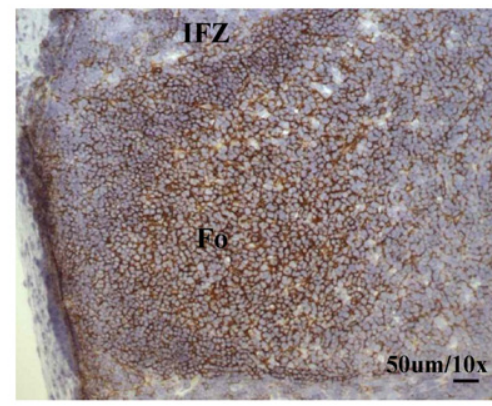

(F)

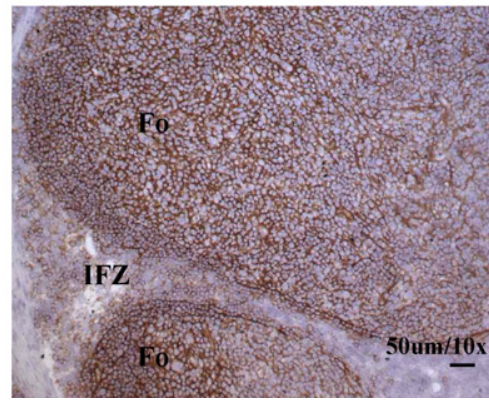

(E)

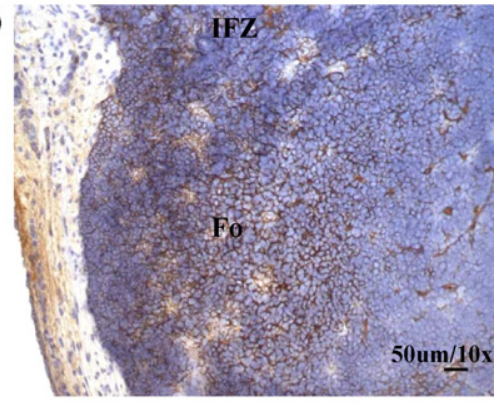

(G)

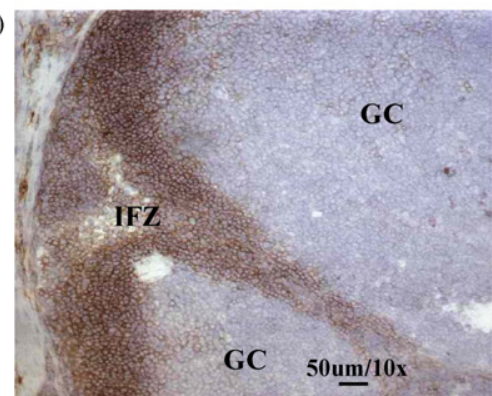

Fig. 1. Retropharyngeal lymph node of newborn (A, B, C) and 7-month-old calves (D, E, F, G) stained with monoclonal antibodies for CD21 (A, D, F), IgM $(B, E)$ and CD32 (C, G). Figures A and B are serial sections from RPLN of a newborn calf and show similar distribution of CD21+ and IgM ${ }^{+}$cells in the cortical area. Figures D and E are serial sections from RPLN of a 7-month-old calf and show similar distribution of $\mathrm{CD}_{21}{ }^{+}$and $\mathrm{IgM}^{+}$cells in the cortical area. Figures $\mathrm{F}$ and $\mathrm{G}$ are serial sections from RPLN of a 7-month-old calf and show differences in distribution of CD21 ${ }^{+}$and $\mathrm{CD} 32^{+}$cells. Magnification is indicated by the bar in each image. Fo = follicle, IFZ= interfollicular zone, GC= germinal center.

separately with appropriate dilutions of mouse monoclonal antibodies $(\mathrm{mAb})$ directed against bovine $\mathrm{CD} 21$, IgM, CD32 and the 28-kDa surface antigen of bovine FDC (referred to as anti-FDC) (Table 1). Lectin from Arachis hypogaea (peanut agglutinin [Sigma], working dilution 1:400) was used to detect GCs (Coico et al., 1983). To stain for CD21, IgM or GCs, slides were incubated with the working dilution of mAbs or peanut agglutinin for $1 \mathrm{~h}$ at RT, whereas for CD32 and FDC, slides were incubated overnight at $4{ }^{\circ} \mathrm{C}$. A goat anti-mouse/anti-rabbit immunoglobulin (EnVision ${ }^{\mathrm{TM}_{+}}$dual link) polymer detection system (Dako) was used as the secondary antibody with Nova Red (SK 4800, Vector labs, Peterborough, UK) as chromogen. Sections were counter-stained with Harris haematoxylin for $5 \mathrm{~min}$, followed by destaining in $1 \%$ acid alcohol (1\% hydrochloric acid in $70 \%$ alcohol) and weak ammonia solution. Cover slips were applied using glycerol-mounting medium (Dako) and slides were kept at RT until examined by light microscopy (Leica DM RA2).

\section{Results}

\subsection{Newborn calves}

The cortex of the RPLN was small in size and contained few organized primary follicles. Most of the $\mathrm{CD} 21^{+}$cells were in the subcapsular region and cortex; only a few cells were present in the paracortex and medulla (Fig. 1A). IgM and CD21 positive cells exhibited the same staining patterns and were located in the same regions (Fig. 1B). $\mathrm{CD}_{3}{ }^{+}$cells were scarce and detected primarily in the paracortex and medulla. These cells could be lymphocytes, macrophages or dendritic cells (Fig. 1C). There was minimal CD32 staining in the cortex.

In the spleen, cells demonstrating CD21 and IgM immunoreactivity were present primarily in the marginal zone of the white pulp (Fig. 2A, B). There were no recognizable GCs or lymphoid follicles around the periarteriolar lymphoid sheath (PALS) (Fig. 2A, B). A few IgM $^{+}$ cells were scattered in the red pulp of spleen consistent 
(A)

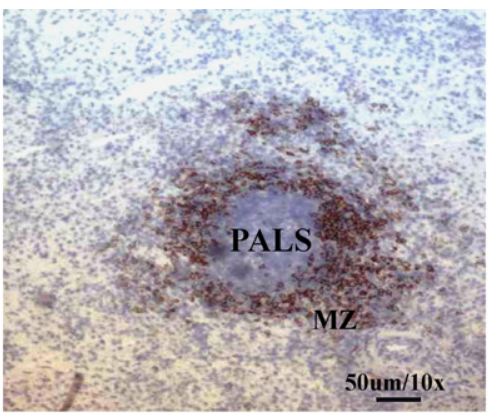

(B)

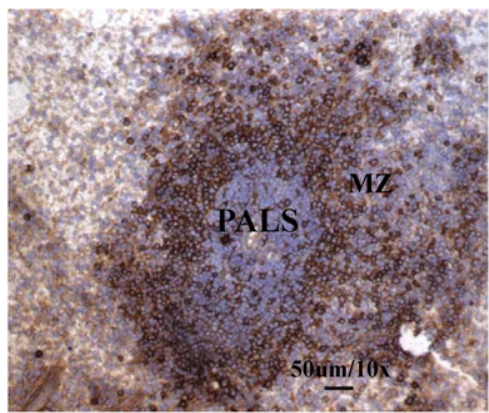

(C)

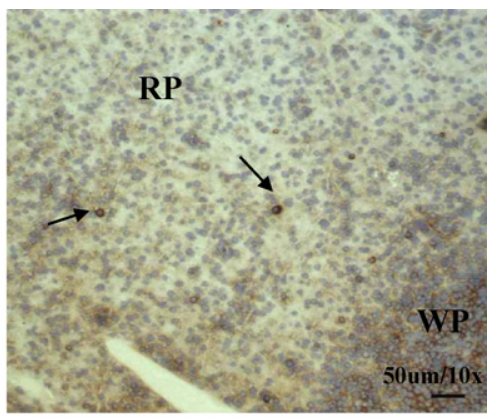

(D)

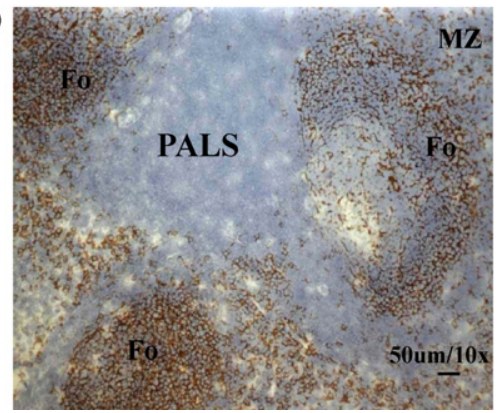

(E)

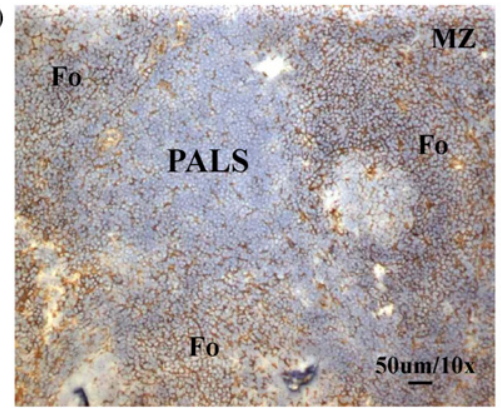

Fig. 2. Spleen of newborn (A, B, C) and 7-month-old calves (D, E) stained with monoclonal antibodies for CD21 (A, D) and IgM (B, C, E). Arrows indicates plasma cells in the red pulp (C). Figures A and B are serial sections from spleen of a newborn calf and show similar distribution of staining for CD2 ${ }^{+}$and $\mathrm{IgM}^{+}$cells. Figures D and E are serial sections from spleen of a 7-month-old calf and show similar distribution for CD21 ${ }^{+}$and IgM ${ }^{+}$cells. Magnification is indicated by the bar in each image. $\mathrm{PALS}=$ periarteriolar lymphoid sheath, $\mathrm{MZ}=$ marginal zone, $\mathrm{RP}=\mathrm{red}$ pulp, $\mathrm{WP}=\mathrm{white}$ pulp, Fo = follicle.

with the staining pattern and morphology expected for plasma cells (Fig. 2C). Subjectively, staining for IgM and CD21 was less extensive in newborns compared to older calves.
In palatine tonsils, as in lymph nodes, CD21 and IgM positive cells had identical staining patterns and were present in the sub-epithelium, as scattered cells or organized lymphoid follicles (Fig. 3A, B). A few $\operatorname{IgM}^{+}$cells were also
(A)

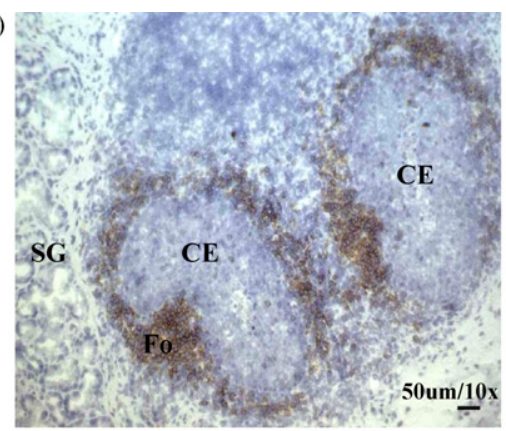

(B)

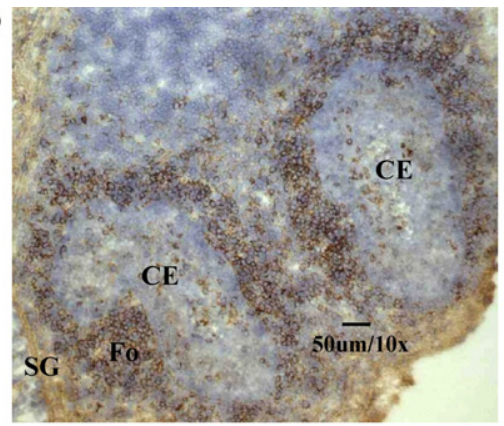

(C)

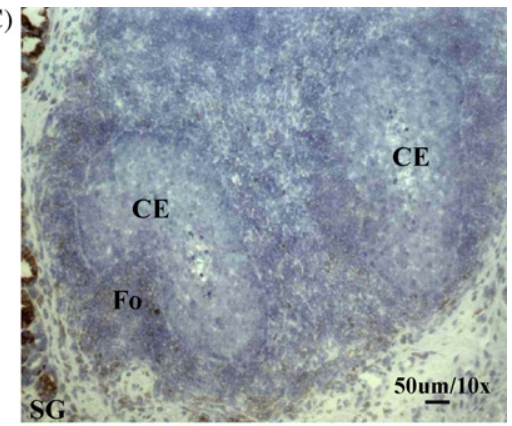

(D)

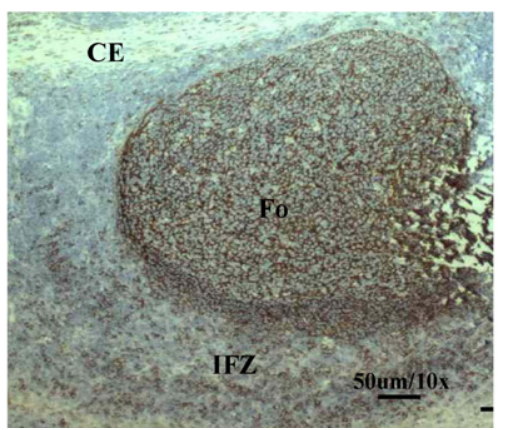

(E)

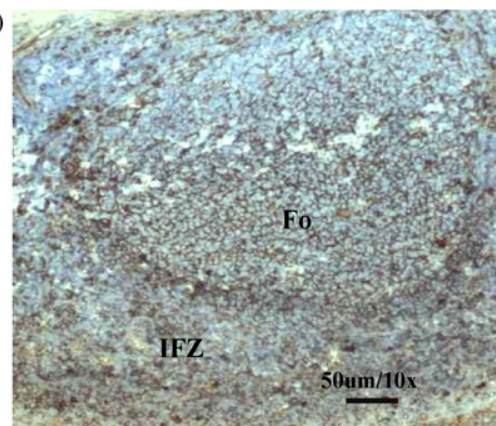

Fig. 3. Palatine tonsils of newborn (A, B, C) and 7-month-old calves (D, E) stained with monoclonal antibodies for CD21 (A, D), IgM (B, E) and CD32 (C). Figures A, B and C are serial sections from tonsil of a newborn calf and show similar distribution for CD21 $1^{+}$, IgM ${ }^{+}$cells and minimal expression of CD32. Figures $\mathrm{D}$ and $\mathrm{E}$ are serial sections from tonsil of a 7-month-old calf and show similar distribution for $\mathrm{CD} 21^{+}$and $\operatorname{lgM}^{+}$cells. Magnification is indicated by the bar in each image. $S G$ = salivary gland, $C E=$ crypt epithelium, Fo = follicle, IFZ=interfollicular zone. 


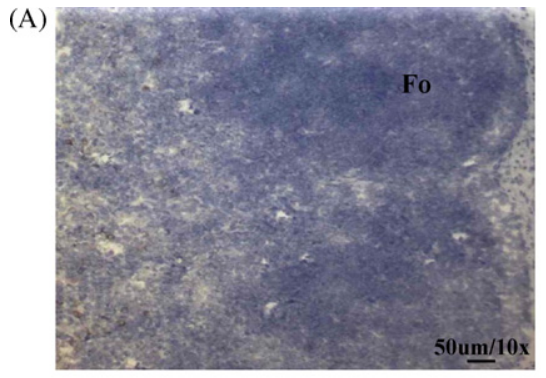

(D)

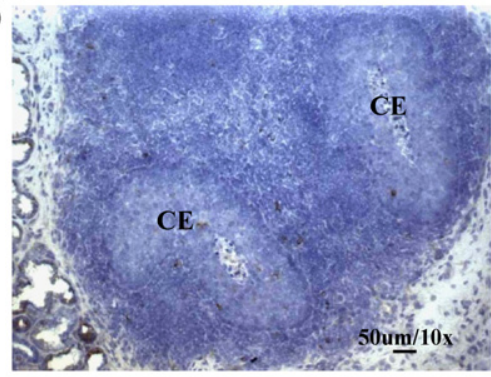

(F)

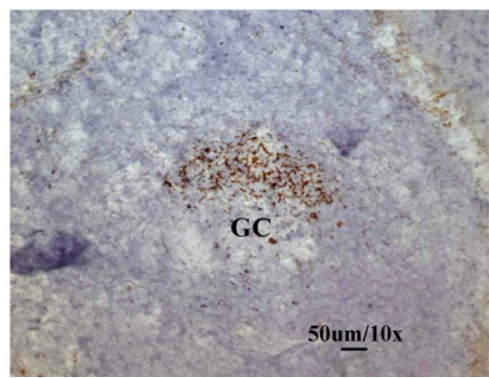

(B)

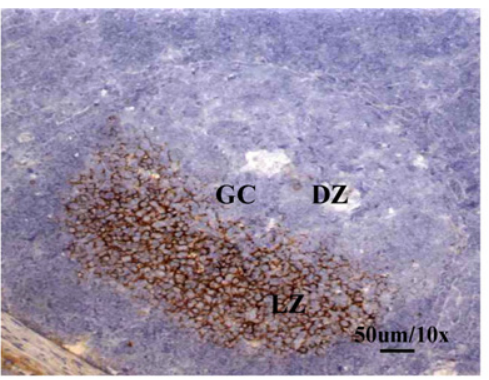

(C)

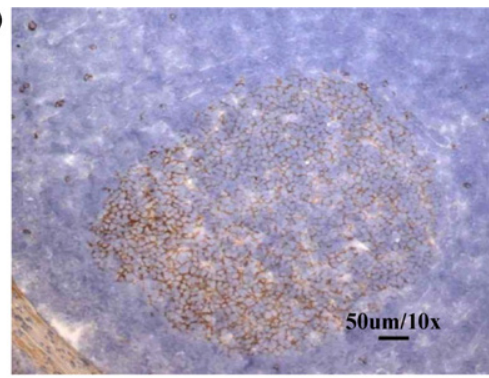

(E)

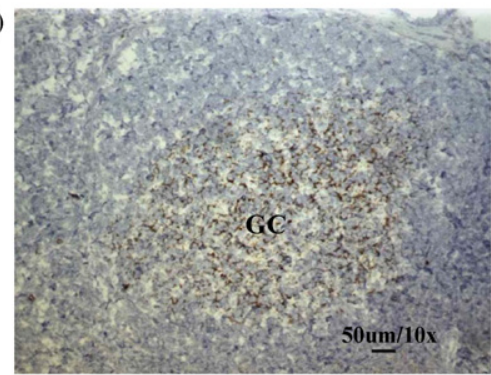

(G)

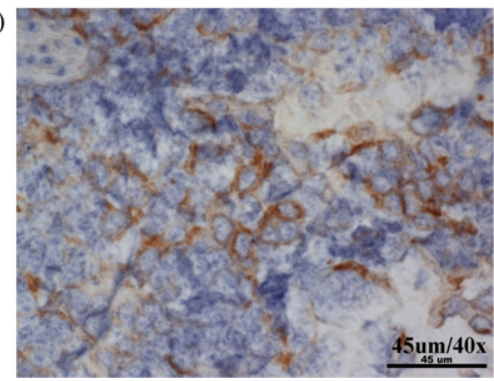

Fig. 4. Staining for follicular dendritic cells in retropharyngeal lymph node (RPLN) of newborn (A) and 7-month-old calves (B, G), in palatine tonsils of newborn (D) and 7-month-old calves (E), and in spleen of a 7-month-old calf (F). Peanut agglutinin was used to identify germinal centers in RPLN of a 7 -month-old calf (C). Fig. G shows mesh like network of FDCs at higher magnification $(40 \times)$. Magnification is indicated by the bar in each image. Fo $=$ follicle, $\mathrm{GC}=$ germinal center, $\mathrm{LZ}=$ light zone, $\mathrm{DZ}=$ dark zone, $\mathrm{CE}=$ crypt epithelium.

detected within crypt epithelium (Fig. 3B). CD32 staining was weak, staining only a few cells in the lymphoid follicles and showed some overlap with CD21 and IgM staining (Fig. 3C).

FDCs could not be detected in RPLN, spleen or palatine tonsils of newborn calves (Fig. 4A, D).

\subsection{7-Month-old calves}

In RPLN, CD21 and IgM positive cells showed overlapping patterns of staining in the mantle zone of the follicles and in the paracortical area (Fig. 1D, E). CD2 $1^{+}$cells were also present within the follicles suggesting expression on centroblasts (rapidly proliferating lymphocytes in the dark zone of GC), centrocytes (lymphocytes in the light zone of GC with low rates of proliferation) and FDCs (Fig. 1F). CD32 was primarily detected in the corona of follicles, interfollicular area and paracortex whereas almost no staining was detected in the GCs suggesting absence of this receptor on centroblasts and centrocytes (Fig. 1G).

In spleen, $\mathrm{CD} 21^{+}$and $\mathrm{IgM}^{+}$cells showed overlapping staining patterns in the follicles around the PALS and in the marginal zone of the white pulp (Fig. 2D, E). CD32 staining overlapped with CD21 except for minimal staining in the GCs (data not shown).

In palatine tonsils, CD21 and IgM staining was detected in the mantle zone and GCs of lymphoid follicles, and in the interfollicular zone (Fig. 3D, E).

PNA was used to identify GCs and the staining patterns were compared to those for other antibodies to confirm the presence of stained cells in GCs (Fig. 4C). FDCs in a characteristic mesh-like network were detected in lymphoid follicles of retropharyngeal lymph nodes and spleen and in lymphoid aggregates in palatine tonsils (Fig. 4B, E, F, G). FDCs were present primarily in the light zone, with few in the dark zones of GCs. Cells in these regions stained with $\mathrm{CD} 21 \mathrm{mAb}$ as well, suggesting co-expression of this receptor (Figs. 1F, 2D, 3D). Cells in the FDC regions also stained with anti-IgM mAb suggesting display of IgM complexes on FDCs or their interaction with $\operatorname{IgM}^{+} \mathrm{B}$ cells (data not shown).

\section{Discussion}

This study was completed to determine the spatial distribution of CD21, IgM and CD32 expressing cells in the lymphoid tissues and is supplementary to an earlier 
investigation showing expression of CD21 and CD32 on $\mathrm{IgM}^{+}$cells in lymphoid tissues of calves by flow cytometry (Chattha et al., 2010b). In addition, this is the first study to investigate the appearance of FDCs with age in cattle. FDCs are important for antibody responses and their absence may result in limited responses in newborns (Pihlgren et al., 2003).

Our previous study using flow cytometry showed that greater than $90 \%$ of $\mathrm{IgM}^{+}$cells in the spleen and lymph nodes of newborn calves express CD21. The present study shows a major overlap in immunostaining patterns for CD21 and IgM in these tissues in both newborns and 7-month-old calves. Because CD21 is the receptor for complement $\mathrm{C} 3 \mathrm{~d}$, these findings suggest that B cells in the lymphoid tissues of newborns can be activated by complement-containing antigen or adjuvants (Pihlgren et al., 2004). A recent study has shown a previously unsuspected role for CD21 on B cells in carrying and transferring antigen-antibody complexes from subcapsular sinus macrophages to the FDCs in the lymph nodes (Phan et al., 2007). The absence of FDCs in neonates may be a major limitation for employment of this mechanism in the generation of antibody responses.

The presence of $C D 21$ expressing lymphocytes in the marginal zone of the spleen in newborn calves suggests that expression of this receptor may not be a limiting factor for $\mathrm{T}$ independent responses as observed in human neonates and infants (Timens et al., 1989). However, the overall reduced number of B cells expressing CD21 and IgM, in this age group may impose constraints on B cell responses and delay the kinetics of antibody production. Since antigenic stimulation was minimal in the animals used in this study, the lack of organized GCs in the spleen of newborn calves was not surprising. In rats B cell follicles are not apparent histologically before 2 weeks of age and GCs appear by 3-4 weeks of age (Dijkstra and Dopp, 1983), whereas GCs are not observed in human neonates until several months after birth (Namikawa et al., 1986).

Similar to human lymphoid tissues, immunostaining for CD32 was limited mainly to the mantle zone of the follicles suggesting that not all the $\operatorname{IgM}^{+}$cells express CD32 (Tuijnman et al., 1993). This finding correlates with flow cytometry data showing that only $75 \%$ to $83 \%$ of $\operatorname{IgM}^{+}$cells express CD32 in newborn and older calves (Chattha et al., 2010b). The reduced expression of CD32 on centroblasts and centrocytes has been demonstrated by flow cytometry in the human tonsil GCs (Macardle et al., 2002). It has been hypothesized that reduced expression of CD32 may play an important role in selection and affinity maturation of B lymphocytes in GC reactions (Macardle et al., 2002). In the 7-month-old calves we observed minimal immunostaining for CD32 in the region of FDCs in the GC suggesting low-level expression of this receptor on FDCs. This receptor has been suggested to play a role in displaying immune complexes (Tew et al., 1997).

The absence of follicular dendritic cells in newborn calves is an important finding and may limit early GC reactions, including generation of antibody secreting cells and memory cells. In mice, adult equivalent patterns for FDCs appear by 3 weeks of age (Pihlgren et al., 2003) whereas mature FDC networks appear by 2 months of age in humans
(Timens et al., 1989). Investigations in neonatal mice have shown that FDC precursors are unresponsive to B cell associated factors such as TNF- $\alpha$, LT- $\alpha$ and LT- $\beta$, which are considered essential for maturation of FDC networks in adults (Fu and Chaplin, 1999; Pihlgren et al., 2003). The appearance of mature FDC networks in the lymph nodes of 7-week-old calves (data not shown) suggests appearance of these cells somewhere between a week and 2 months of age. Thus, early immunization may result in limited B cell responses in neonatal calves, whereas vaccination after this time is more likely to be efficacious.

The marker detected by FDC-B1 mAb is not known. There is a possibility that mature FDCs may exist in newborn calves with minimal or no expression of the particular antigen recognized by FDC-B1 $\mathrm{mAb}$. However, we could not identify CD21 $1^{+}$cells with FDC morphology, indirectly suggesting that FDC were absent from the lymphoid tissues. Likewise the failure to observe organized follicles in lymphoid tissues can also be attributed to absence of mature FDCs in newborn calves. Interestingly, regions with FDCs also exhibited staining with anti-IgM mAb in 7-monthold calves (data not shown) indicating that IgM-antigen or IgM-complement-antigen complexes could be retained by FDCs. This retention may occur through either a complement receptor or the suggested presence of an Fc alpha/mu receptor $(\mathrm{Fc} \alpha / \mu \mathrm{R})$ in cattle similar to humans (Kikuno et al., 2007).

In brief, the co-location of $\operatorname{IgM}^{+}$and $\mathrm{CD} 21^{+}$cells is consistent with observations from our flow cytometry study, which found that the majority of the $\mathrm{IgM}^{+}$cells in the lymphoid tissues of newborns express the activating receptor CD21, but a lower proportion express the inhibitory receptor CD32. Therefore, C3d tagged antigens might be effective in driving antibody responses in the neonate despite the presence of maternal antibodies. B cells with minimal expression or absence of CD32 occur in GCs. However, the low number of $B$ lymphocytes and the minimal number of FDCs in the lymphoid tissues are important limitations for neonatal antibody responses following immunization. Discovering means to accelerate FDC maturation in newborns will be an important milestone on the road to effective neonatal vaccines.

\section{Acknowledgements}

This research was funded by the Natural Sciences and Engineering Research Council of Canada (NSERC), the Canadian Cattlemen's Association (Beef Cattle Research Council), the Dairy Farmers of Canada, the Ontario Cattlemen's Association (Agricultural Adaptation Council), the Alberta Beef Producers with the Alberta Livestock and Meat Agency, and the Ontario Ministry of Agriculture, Food and Rural Affairs. mAb anti-bovine CD32 was provided by the BBSRC/SEERAD Immunological Toolbox (grant numbers BBS/B/00255, MRI/094/04); the kindness of Dr Jayne Hope is appreciated. Thanks are due to the Canadian Commonwealth Scholarship Program and the B.C. Cattlemen's Association (Brigadier Bostock Fellowship) for financial assistance to Kuldeep Singh Chattha. We would like to thank Betty-Anne McBey and Eric Pringle for providing assistance and technical help collecting and processing 
animal samples. We also appreciate the assistance and cooperation of the staff of the Elora and Ponsonby Dairy Research Stations.

\section{References}

Amigorena, S., Bonnerot, C., Drake, J.R., Choquet, D., Hunziker, W., Guillet J.G., Webster, P., Sautes, C., Mellman, I., Fridman, W.H., 1992. Cytoplasmic domain heterogeneity and functions of IgG Fc receptors in B lymphocytes. Science 256 (5065), 1808-1812.

Chase, C.C., Hurley, D.J., Reber, A.J., 2008. Neonatal immune development in the calf and its impact on vaccine response. Vet. Clin. North Am. Food Anim. Pract. 24 (1), 87-104.

Chattha, K.S., Firth, M.A., Hodgins, D.C., Shewen, P.E., 2009. Age related variation in expression of CD21 and CD32 on bovine lymphocytes: a cross-sectional study. Vet. Immunol. Immunopathol. 130 (1-2), 70-78.

Chattha, K.S., Firth, M.A., Hodgins, D.C., Shewen, P.E., 2010a. Variation in expression of membrane IgM, CD21 (CR2) and CD32 (Fc $\gamma$ RIIB) on bovine lymphocytes with age: a longitudinal study. Dev. Comp. Immunol. 34 (5), 510-517.

Chattha, K.S., Firth, M.A., Hodgins, D.C., Shewen, P.E., 2010b. Expression of complement receptor 2 (CD21), membrane IgM and the inhibitory receptor $\mathrm{CD} 32$ (Fc $\gamma \mathrm{RIIb})$ in the lymphoid tissues of neonatal calves. Vet. Immunol. Immunopathol. doi:10.1016/j.vetimm.2010.04.016.

Coico, R.F., Bhogal, B.S., Thorbecke, G.J., 1983. Relationship of germinal centers in lymphoid tissue to immunologic memory: VI. Transfer of B cell memory with lymph node cells fractionated according to their receptors for peanut agglutinin. J. Immunol. 131 (5), 2254-2257.

Dempsey, P.W., Allison, M.E., Akkaraju, S., Goodnow, C.C., Fearon, D.T. 1996. C3d of complement as a molecular adjuvant: bridging innate and acquired immunity. Science 271 (5247), 348-350.

Dijkstra, C.D., Dopp, E.A., 1983. Ontogenetic development of T- and Blymphocytes and non-lymphoid cells in the white pulp of the rat spleen. Cell Tissue Res. 229 (2), 351-363.

Firth, M.A., Shewen, P.E., Hodgins, D.C., 2005. Passive and active components of neonatal innate immune defenses. Anim. Health Res. Rev. 6 (2), 143-158.

Fu, Y.X., Chaplin, D.D., 1999. Development and maturation of secondary lymphoid tissues. Annu. Rev. Immunol. 17, 399-433.

Gergely, J., Sarmay, G., 1996. Fc gamma RII-mediated regulation of human B cells. Scand. J. Immunol. 44 (1), 1-10.

Kaur, K., Chowdhury, S., Greenspan, N.S., Schreiber, J.R., 2007. Decreased expression of tumor necrosis factor family receptors involved in humoral immune responses in preterm neonates. Blood 110 (8), 2948-2954.

Kikuno, K., Kang, D.W., Tahara, K., Torii, I., Kubagawa, H.M., Ho, K.J., Baudino, L., Nishizaki, N., Shibuya, A., Kubagawa, H., 2007. Unusual biochemical features and follicular dendritic cell expression of Fcalpha/mu receptor. Eur. J. Immunol. 37 (12), 3540-3550.

Lyubchenko, T., dal Porto, J., Cambier, J.C., Holers, V.M., 2005. Coligation of the B cell receptor with complement receptor type 2 (CR2/CD21) using its natural ligand C3dg: activation without engagement of an inhibitory signaling pathway. J. Immunol. 174 (6), 3264-3272.

Macardle, P.J., Mardell, C., Bailey, S., Wheatland, L., Ho, A., Jessup, C., Roberton, D.M., Zola, H., 2002. FcgammaRIIb expression on human germinal center B lymphocytes. Eur. J. Immunol. 32 (12), 3736-3744.
Marshall-Clarke, S., Reen, D., Tasker, L., Hassan, J., 2000. Neonatal immunity: how well has it grown up? Immunol. Today 21 (1), 3541.

Melot, F., Defaweux, V., Jolois, O., Collard, A., Robert, B., Heinen, E., Antoine, N., 2004. FDC-B1: a new monoclonal antibody directed against bovine follicular dendritic cells. Vet. Immunol. Immunopathol. 97 (1-2), $1-9$.

Muthukkumar, S., Goldstein, J., Stein, K.E., 2000. The ability of B cells and dendritic cells to present antigen increases during ontogeny. J. Immunol. 165 (9), 4803-4813.

Namikawa, R., Mizuno, T., Matsuoka, H., Fukami, H., Ueda, R., Itoh, G. Matsuyama, M., Takahashi, T., 1986. Ontogenic development of T and B cells and non-lymphoid cells in the white pulp of human spleen. Immunology 57 (1), 61-69.

Nimmerjahn, F., Ravetch, J.V., 2008. Fc gamma receptors as regulators of immune responses. Nat. Rev. Immunol. 8 (1), 34-47.

Phan, T.G., Grigorova, I., Okada, T., Cyster, J.G., 2007. Subcapsular encounter and complement-dependent transport of immune complexes by lymph node B cells. Nat. Immunol. 8 (9), 992-1000.

Pihlgren, M., Fulurija, A., Villiers, M.B., Tougne, C., Lambert, P.H., Villiers, C.L., Siegrist, C.A., 2004. Influence of complement C3 amount on IgG responses in early life: immunization with $\mathrm{C} 3 \mathrm{~b}$-conjugated antigen increases murine neonatal antibody responses. Vaccine 23 (3) 329-335.

Pihlgren, M., Tougne, C., Bozzotti, P., Fulurija, A., Duchosal, M.A., Lambert, P.H., Siegrist, C.A., 2003. Unresponsiveness to lymphoid-mediated signals at the neonatal follicular dendritic cell precursor level contributes to delayed germinal center induction and limitations of neonatal antibody responses to T-dependent antigens. J. Immunol. 170 (6), 2824-2832.

Rijkers, G.T., Sanders, E.A., Breukels, M.A., Zegers, B.J., 1998. Infant B cell responses to polysaccharide determinants. Vaccine 16 (14-15), $1396-1400$.

Siegrist, C.A., 2001. Neonatal and early life vaccinology. Vaccine 19 (25-26), 3331-3346.

Siegrist, C.A., Aspinall, R., 2009. B-cell responses to vaccination at the extremes of age. Nat. Rev. Immunol. 9 (3), 185-194.

Tew, J.G., Wu, J., Fakher, M., Szakal, A.K., Qin, D., 2001. Follicular dendritic cells: beyond the necessity of T-cell help. Trends Immunol. 22 (7), 361-367.

Tew, J.G., Wu, J., Qin, D., Helm, S., Burton, G.F., Szakal, A.K., 1997. Follicular dendritic cells and presentation of antigen and costimulatory signals to B cells. Immunol. Rev. 156, 39-52.

Timens, W., Boes, A., Rozeboom-Uiterwijk, T., Poppema, S., 1989. Immaturity of the human splenic marginal zone in infancy. Possible contribution to the deficient infant immune response. J. Immunol. 143 (10), 3200-3206.

Tuijnman, W.B., Van Wichen, D.F., Schuurman, H.J., 1993. Tissue distribution of human IgG Fc receptors CD16, CD32 and CD64: an immunohistochemical study. APMIS 101 (4), 319-329.

Van Den Herik-Oudijk, I.E., Westerdaal, N.A., Henriquez, N.V., Capel, P.J., Van De Winkel, J.G., 1994. Functional analysis of human Fc gamma RII (CD32) isoforms expressed in B lymphocytes. J. Immunol. 152 (2), 574-585. 